\title{
Correction to: Risk of stress/depression and functional impairment in Denmark immediately following a COVID-19 shutdown
}

\author{
Lars H. Andersen ${ }^{1 *}$, Peter Fallesen ${ }^{1,2}$ and Tim A. Bruckner ${ }^{3}$
}

\section{Correction to: BMC Public Health 21, 984 (2021)}

https://doi.org/10.1186/s12889-021-11020-3

It was highlighted that the original article [1] contained some errors in the references. The title of reference [2] was incorrect and a new reference had to be added and cited in the Discussion section of the text. This correction article shows the correct reference [2], the new reference [3] and its in-text citation. The reference list in the text has been renumbered from reference [3] onwards. The original article has been updated.

\section{Discussion p.8}

Denmark, although mental wellbeing (also measured using the WHO-5) in that study is observed only after the lockdown, from early to late April (i.e., that study has no pre lockdown "baseline" but still documents improved mental wellbeing from early to late April) [3].

\section{Author details}

'ROCKWOOL Foundation, Ny Kongensgade 6, 1472 Copenhagen C, Denmark. ${ }^{2}$ Swedish Institute for Social Research, Stockholm University, 10691 Stockholm, Sweden. ${ }^{3}$ Program in Public Health and the Center for Population, Inequality and Policy, University of California, Irvine, CA 92697-3957, USA.

Published online: 16 June 2021

\section{References}

1. Andersen, et al. Risk of stress/depression and functional impairment in Denmark immediately following a COVID-19 shutdown. BMC Public Health. 2021;21:984. https://doi.org/10.1186/s12889-021-11020-3.

The original article can be found online at https://doi.org/10.1186/s12889021-11020-3.

* Correspondence: Iha@rff.dk

${ }^{1}$ ROCKWOOL Foundation, Ny Kongensgade 6, 1472 Copenhagen C, Denmark Full list of author information is available at the end of the article
2. Sønderskov K, Dinesen $P$, Santini Z, Østergaard S. The depressive state of Denmark during the COVID-19 pandemic. Acta Neuropsychiatrica. 2020; 32(4):226-8 https://doi.org/10.1017/neu.2020.15.

3. Sønderskov K, Dinesen P, Santini Z, Østergaard S. Increased psychological well-being after the apex of the COVID-19 pandemic. Acta Neuropsychiatrica. 2020;32(5):277-9. https://doi.org/10.1017/neu.2020.26.

(c) The Author(s). 2021 Open Access This article is licensed under a Creative Commons Attribution 4.0 International License, which permits use, sharing, adaptation, distribution and reproduction in any medium or format, as long as you give appropriate credit to the original author(s) and the source, provide a link to the Creative Commons licence, and indicate if changes were made. The images or other third party material in this article are included in the article's Creative Commons licence, unless indicated otherwise in a credit line to the material. If material is not included in the article's Creative Commons licence and your intended use is not permitted by statutory regulation or exceeds the permitted use, you will need to obtain permission directly from the copyright holder. To view a copy of this licence, visit http://creativecommons.org/licenses/by/4.0/. The Creative Commons Public Domain Dedication waiver (http://creativecommons.org/publicdomain/zero/1.0/) applies to the data made available in this article, unless otherwise stated in a credit line to the data. 